Stepan V. T. Renoprotective action of mucosa-adhesive phytogel "Biotrit" in rats, treated with oral application peroxide sunflower oil. Journal of Education, Health and Sport. 2020;10(11):89-95. eISSN 2391-8306. DOI http://dx.doi.org/10.12775/JEHS.2020.10.11.009

https://apcz.umk.pl/czasopisma/index.php/JEHS/article/view/JEHS.2020.10.11.009

https://zenodo.org/record/4277964

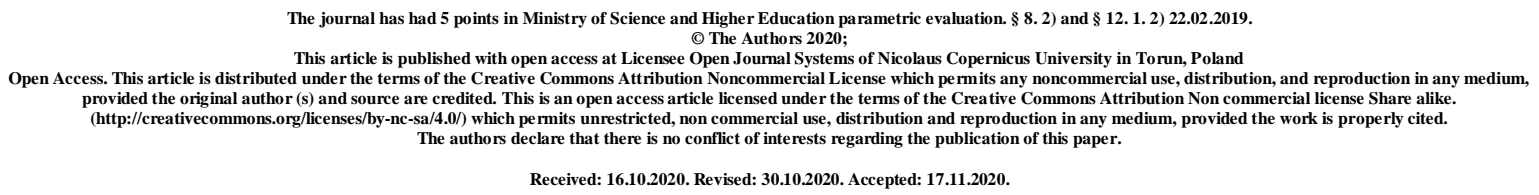

UDK 616.61:616.821:612.31

\title{
RENOPROTECTIVE ACTION OF MUCOSA-ADHESIVE PHYTOGEL "BIOTRIT" IN RATS, TREATED WITH ORAL APPLICATION PEROXIDE SUNFLOWER OIL
}

\author{
V. T. Stepan
}

\section{Bukovina State Medical University, Chernovtsy}

\section{Abstract}

Aim. Determine the renoprotective activity of oral "Biotrit" gel when exposed to peroxide sunflower oil (PSO).

Methods. PSO was obtained by heating the oil at $+180^{\circ} \mathrm{C}$ for 60 minutes in the presence of $1.5 \% \mathrm{H}_{2} \mathrm{O}_{2}$. Used mucosa-adhesive phytogel "Biotrit", containing bioflavonoids from wheat leaves. Rats received oral applications of PSO at a dose of $0.5 \mathrm{ml} / \mathrm{rat}$ for 5 days. A part of the rats received 30 minutes before the application of the PSO application of the "Biotrit" gel. The activity of elastase, catalase, urease, lysozyme and the content of MDA were determined in the kidneys. The ratio of catalase and MDA was calculated the API index, and the ratio of the relative activities of urease and lysozyme - the degree of dysbiosis.

Results. In rats treated with PSO, the activity of elastase, urease, and MDA content increased but lysozyme activity and the API index decreased in the kidneys. Applications of the gel "Biotrit" reduce the activity of elastase, urease, increase the activity of lysozyme and the API index.

Conclusion. Consumption of PSO causes the development of nephropathy; Oral applications of the gel "Biotrit" prevent the development of peroxide nephropathy. 
Key words: kidney; nephropathy; oral cavity; peroxide oil; phytogel; bioflavonoids.

\section{Introduction}

Unsaturated fatty acids that are part of edible fats are easily peroxidized both during storage and, especially, during thermal cooking [1-3]. The resulting peroxidation products (hydroperoxides, aldehydes, ketones, and other compounds) have a toxic effect on the body $[4,5]$. The pathogenic effect of peroxide sunflower oil (PSO) on the state of the tissues of the oral cavity has been established $[6,7]$. The pathological consequences of PSO consumption can be prevented with the help of flavan-containing agents $[8,9]$.

Our attention was attracted by the drug Biotrit, which has proven itself in experiment and in the clinic, which contains bioflavonoids from wheat seedlings [10-13]. We have chosen for research the dosage form of Biotrit in the form of a mucose-adhesive phytogel [14, $15]$.

The aim of this work was to determine the renoprotective effect of the Biotrit phytogel when exposed to PSO in rats.

\section{Material and research methods}

To obtain PSO, unrefined sunflower oil was heated at $+180{ }^{\circ} \mathrm{C}$ in the presence of $1.5 \%$ $\mathrm{H}_{2} \mathrm{O}_{2}(30 \%)$ for 60 minutes.

In the work was used mucose-adhesive phytogel "Biotrit", produced by SPA "Odessa Biotechnology" [16].

The experiments were carried out on 18 white Wistar rats (females, 4-5 months., $210 \pm 12 \mathrm{~g}$ ), distributed into 3 equal groups: $1 \mathrm{st}$ - control, received compound feed, the recipe of which is presented in table 1.2 and group 3 received the same diet, but additionally they received oral applications of PSO at a dose of $0.5 \mathrm{ml}$ per rat daily for 5 days. The rats of the 3rd group received application of the Biotrit gel at a dose of $0.5 \mathrm{ml}$ per rat for 5 days 30 minutes before the PSO application.

After the euthanasia of the animals on the 6th day, the kidneys were removed and the level of biochemical markers of inflammation was determined in the homogenate of the animals [17]: the activity of elastase by the hydrolysis of a synthetic substrate [18] and the content of malondialdehyde (MDA) by the thiobarbituric method [19]. The activities of catalase [20], urease [21], and lysozyme [22] were also determined. 
Table1. Composition of compound feed for rats

\begin{tabular}{|l|c|}
\hline \multicolumn{1}{|c|}{ Components } & Content, $\%$ \\
\hline Wheat grain, crushed & 80 \\
\hline Soy meal & 15 \\
\hline Mineral mixture [25] & 4 \\
\hline Vitamin Blend [25] & 1 \\
\hline
\end{tabular}

The antioxidant- prooxidant index of the API was calculated from the ratio of catalase activity and MDA content [17], and from the ratio of the relative activities of urease and lysozyme, the degree of dysbiosis was calculated according to A. P. Levitsky [23, 24].

Mineral and vitamin mixtures for compound feed were prepared in accordance with the recommendations [25].

The analysis of the peroxidation products and the fatty acid composition of the oil were done in accordance with the recommendations [26].

The experimental results were subjected to standard statistic processing [27].

\section{Results and discussion}

Table 2 shows that after heat treatment of sunflower oil, the content of diene conjugates in it increased by 6 times, and the content of MDA by almost 14 times, while the content of linoleic acid $\left(\mathrm{C}_{18: 2}\right)$ decreased.

Table 2. Indicators of peroxide of sunflower oil

\begin{tabular}{|l|c|c|}
\hline \multicolumn{1}{|c|}{ Indicators } & Native sunflower oil & PSO \\
\hline Diene conjugates, $\mathrm{mmol} / \mathrm{l}$ & 2,5 & 15,0 \\
\hline MDA, mmol / 1 & 0,51 & 6,92 \\
\hline Linoleic acid,\% & 53,8 & 52,7 \\
\hline
\end{tabular}

Table 3 shows the results of determining the level of inflammation markers in the kidneys of rats treated with PSO. It can be seen that both indicators significantly increase: elastase activity by $20 \%$, and MDA content by $50 \%$. Oral applications of Biotrit gel reduce both indicators of inflammation.

Table 4 shows the results of determining the activity of the antioxidant enzyme catalase and the API index. It can be seen that the activity of catalase does not change both with the introduction of PSO, and after the application of the Biotrit gel. At the same time, the API index significantly decreases, indicating a disruption in the balance of antioxidant and 
prooxidant systems in favor of the latter. Oral applications of Biotrit gel restore the balance of these systems.

Table 3. Influence of Biotrit gel on the level of inflammation markers in the kidneys of rats treated with oral applications of peroxide sunflower oil (PSO)

( $\mathrm{n}=6$ in all groups)

\begin{tabular}{|c|l|c|c|}
\hline № & \multicolumn{1}{|c|}{ Groups } & Elastase, mk-cat / kg & MDA, mmol / kg \\
\hline 1 & Control & $327 \pm 12$ & $33,0 \pm 1,8$ \\
\hline 2 & PSO, 5 days & $391 \pm 24$ & $49,6 \pm 3,7$ \\
& & $\mathrm{p}<0,05$ & $\mathrm{p}<0,001$ \\
\hline 3 & PSO, 5 days + Biotrit gel & $345 \pm 16$ & $37,2 \pm 0,9$ \\
& & $\mathrm{p}>0,3 ; \mathrm{p}_{1}>0,05$ & $\mathrm{p}<0,05 ; \mathrm{p}_{1}<0,01$ \\
\hline
\end{tabular}

Notes: $\mathrm{p}$ - in comparison with gr. 1; p1 - in comparison with gr. 2.

Table 4. Influence of Biotrit gel on catalase activity and antioxidant-prooxidant index of API in the kidneys of rats receiving oral applications of peroxide sunflower oil (PSO)

( $\mathrm{n}=6$ in all groups)

\begin{tabular}{|c|l|c|c|}
\hline $\begin{array}{c}\text { №oo } \\
\Pi \Pi\end{array}$ & \multicolumn{1}{|c|}{ Groups } & Catalase, mkat $/ \mathrm{kg}$ & API \\
\hline 1 & Control & $5,78 \pm 0,18$ & $1,75 \pm 0,08$ \\
\hline 2 & PSO, 5 days & $5,76 \pm 0,06$ & $1,16 \pm 0,10$ \\
& & $\mathrm{p}>0,05$ & $\mathrm{p}<0,01$ \\
\hline 3 & PSO, 5 days + Biotrit gel & $5,86 \pm 0,04$ & $1,58 \pm 0,07$ \\
& & $\mathrm{p}>0,05 ; \mathrm{p}_{1}>0,05$ & $\mathrm{p}>0,05 ; \mathrm{p}_{1}<0,05$ \\
\hline
\end{tabular}

Notes: see table. 3.

Table 5 shows the results of determining the activity of urease, lysozyme and the degree of dysbiosis in the kidneys. From these data it can be seen that in the rats receiving PSO, in the kidneys, the urease activity significantly increases, indicating an increase in bacterial insemination, which decreases under the influence of oral applications of the Biotrit gel. The activity of lysozyme in the kidneys of rats treated with PSO slightly decreases, but the application of the Biotrit gel significantly increases it. The introduction of PSO and Biotrit applications do not significantly affect the degree of dysbiosis in the kidneys.

Thus, consumption of peroxide sunflower oil causes the development of nephropathy, as evidenced by the growth of markers of inflammation and microbial insemination. The leading pathogenetic mechanism in this process is an increase in lipid peroxidation. Oral applications of Biotrit gel reduce the intensity of lipid peroxidation, as evidenced by a 
decrease in the MDA content and an increase in the API index, as well as an increase in lysozyme activity.

Table 5. The effect of Biotrit gel on the activity of urease, lysozyme and the degree of dysbiosis in the kidneys of rats who received oral applications of peroxide sunflower oil

(PSO)

$$
(\mathrm{n}=6 \text { in all groups) }
$$

\begin{tabular}{|c|l|c|c|c|}
\hline $\begin{array}{c}\text { №№ } \\
\text { Пח }\end{array}$ & \multicolumn{1}{|c|}{ Groups } & $\begin{array}{c}\text { Urease, } \\
\text { mk-cat } / \mathrm{kg}\end{array}$ & $\begin{array}{c}\text { Lysozyme, } \\
\text { unit } / \mathrm{kg}\end{array}$ & $\begin{array}{c}\text { Dysbiosis } \\
\text { degree }\end{array}$ \\
\hline 1 & Control & $0,73 \pm 0,02$ & $1416 \pm 33$ & $1,00 \pm 0,13$ \\
\hline 2 & PSO, 5 days & $0,83 \pm 0,03$ & $1343 \pm 33$ & $1,20 \pm 0,18$ \\
& & $\mathrm{p}<0,05$ & $\mathrm{p}>0,05$ & $\mathrm{p}>0,3$ \\
\hline 3 & PSO, 5 days + Biotrit gel & $0,74 \pm 0,05$ & $1430 \pm 13$ & $1,01 \pm 0,15$ \\
& & $\mathrm{p}>0,5 ; \mathrm{p}_{1}>0,05$ & $\mathrm{p}>0,3 ; \mathrm{p}_{1}<0,05$ & $\mathrm{p}>0,5 ; \mathrm{p}_{1}>0,3$ \\
\hline
\end{tabular}

Notes: see table. 3 .

The results obtained give grounds to recommend the use of phytogel "Biotrit" for the prevention of peroxide nephropathy when consuming thermally processed fats.

\section{Conclusions}

1. The consumption of peroxide dietary fats causes the development of nephropathy.

2. It is possible to prevent the development of peroxide nephropathy with the help of oral applications of the "Biotrit" phytogel.

\section{References}

1. Khajuria A. Lipid peroxidation. Everyman's Sci. 1997; 32(3): 109-113.

2. Wolter R, Jean $\mathrm{Cl}$. Rancissement et antioxydation des lipids en nutrition. Neuropeptides. 1998; 32(1): 203-210.

3. Sarkisian VA, Kochetkova AA, Bessonov VV [and others]. Toxicological characteristics of the main products of lipid oxidation. Nutrition issues. 2016; 85(6): 80-85. (in Russian)

4. Voskresenskiy ON, Levitsky AP. Peroxide lipids in the living organism. Questions of medical chemistry 1970; 16(6): 561-581. (in Russian)

5. Plavinskii SL, Plavinskaia SI. Increased levels of lipid peroxidation products as a risk factor for death in a prospective study. Human physiology. 2002; 28(1): 116-120. (in Russian) 
6. Markov AV. Effect of over-oxidized sunflower oil on the condition of periodontium of rats. Dentistry Bulletin. 2018; 2(103): 14-17. (in Ukrainian)

7. Labush Iu. Z. The development of stomatitis in rats that consumed peroxide sunflower oil. Dentistry Bulletin. 2018; 2: 17-20. (in Ukrainian)

8. Levitsky AP, Makarenko OA, Selivanskaya IA [and others]. The experimental prophylaxis of the peroxide periodontitis by antidysbiotic means. Journal of Education, Health and Sport. 2017; 7(2): 682-693.

9. Markov AV, Labush IuZ, Zubachik VM [and others]. Therapeutic and preventive action flavan-containing antidisbiotic means on a mucose membrane of the oral cavity of the rats, received peroxide sunflower oil. Phytotherapy. 2018; 2: 33-35. (in Ukrainian)

10. Volik NA, Beloklitskaya GF. The new adaptogen "Biotrit" in the complex treatment of the periodontal diseases. Dentistry Bulletin. 2000; 5: 28-30. (in Russian)

11. Demyanenko SA. Mucoprotective and hepatoprotective properties of wheat germ. Dentistry Bulletin. 2008; 5-6: 10-14. (in Russian)

12. Levitsky AP, Manik IG, Demyanenko SA [and others]. The antiviral and immunemodelling characteristics of the preparation of germinating wheat seads. Phytotherapy. 2009; 3: 43-46. (in Russian)

13. Demianenko SA, Levitsky AP, Makarenko OA. The effect of Biotrit on the condition of the oral mucosa of rats with toxic hepatitis on the background of dysbiosis. Dentistry Bulletin. 2010; 1: 4-7. (in Russian)

14. Levitsky AP, Makarenko OA, Denga O. V. [and others]. Phytoadaptogens in the prevention and treatment of dental caries. Odessa, KP OGT, 2013: 119. (in Russian)

15. Levitsky A. P., Makarenko O. A., Selivanskaya I. A. [and others]. The use of mucosal gels in dentistry: method guidelines.].Odessa, KP OGT, 2012: 20. (in Russian)

16. The "Biotrit" phytogel RC U 20.4-13903778-032/4:2014 for TU U 20.413903778-032:2012. Hygienic conclusion of the State Service of Ukraine for food safety and Consumer Protection № 05.03.02-07/43417; 03.07.2014. (in Russian)

17. Levitsky AP, Denga OV, Makarenko OA [and others]. Biochemical markers of inflammation of oral cavity tissue: method guidelines. Odessa, KP OGT, 2010: 16. (in Russian)

18. Levitsky AP, Stefanov AV. The methods of the determination of the activity of elastase and its inhibitors: method guidelines. Kiev, GFK, 2002:15. (in Russian)

19. Levitsky AP, Makarenko OA, Demyanenko SA. Methods of experimental dentistry (teaching aid). Simferopol, Tarpan, 2018: 78. (in Russian) 
20. Girin SV. The modification of the method of the determination of catalase activity in biological substrates. Laboratory diagnosis. 1999; 4:45-46. (in Russian)

21. Gavrikova LM, Segen IT. Urease activity of oral liquid in patients with acute odontogenic infection of maxillo-facial part. Stomatology. 1996; The extra issue :49-50. (in Russian)

22. Levitsky AP. Lysozyme instead of antibiotics. Odessa, KP OGT, 2005: 74. (in Russian)

23. Levitsky AP, Denga OV, Selivanskaya IA [and others]. The method of estimation of the degree of dysbiosis (dysbacteriosis) of organs and tissues. Patent of Ukraine 43140. IPC (2009) G01N 33/48. Application number u 200815092. Date of filling: 26.12.2008. Publ.: 10.08.2009. Bul. № 15. (in Ukrainian)

24. Gozhenko A. I., Levitsky A. P., Stepan V. T., Pustovoit I. P., Badiuk N. S., Maslyukov A. K. Advantages of high olein sunflower oil over palm oil according to biochemical research results - PhOL - PharmacologyOnLine - N 2. - P. 293-301. https://pharmacologyonline.silae.it/files/archives/2020/vo12/PhOL_2020_2_A028_Gozhenko. pdf

25. Eggum B. Methods to evaluate utilization of proteins by animal. Moscow: Kolos, 1977: 189. (in Russian)

26. Levitsky AP, Makarenko OA, Khodakov IV. Methods to investigate fats and oils. Odessa, KP OGT, 2015: 32. (in Russian)

27. Truhacheva NV. Mathematical Statistics in biomedical research using application package Statistica. Moskow, GJeOTAR-Media, 2012: 379. (in Russian) 